ISSN : $2302-1590$

E-ISSN: $2460-190 \mathrm{X}$

\title{
ECONOMICA
}

Journal of Economic and Economic Education Vol.1 No.2 (148-161)

\section{PENGEMBANGAN KAWASAN AGROWISATA BBI LUBUAK MINTURUN SEBAGAI DESTINASI UTAMA PARIWISATA SUMATERA BARAT}

\author{
Ansofino \\ Dosen Program Studi Pendidikan Ekonomi STKIP- PGRI Sumbar \\ Jl. Gunung Pangilun No.1, Padang Sumatera Barat. \\ Email : Ansofino2015@yahoo.com \\ submited: 2013.01.20 reviewed: 2013.02.29 accepted: 2013.04.29 \\ http://dx.doi.org/10.22202/economica.2013.v1.i2.115
}

\begin{abstract}
This research focuses on community social economic attraction in agrotourism BBI Lubuk Minturun of West Sumatra region. The method is regional economic approach with tool analyses are location quotient, shift share analysis, and travel cost method to determine integrating linkages of community economic activities in the region. This research shows, first: Padang tourism attraction potency as National activitiy center (PKN) in PP No: 50 year 2011 about National tourism masterplan included in national tourism destination (DPN) together with Bukittinggi. Furthermore, in West Sumatra tourism masterplan, Padang has become Province tourism destination region (DPP) with its strategic destination region (KSPP) are Pesisir Selatan, Padang Pariaman and its potential region is Pariaman city. In the case as DPN, DPP of Padang city has wide tourism potential, approximately 169 tourism destinations to attract foreign and national tourist to visit and spend their leisure time. Second: Kuranji district zone has the highest travel cost on average outside Koto Tangah district in amount of 170,783 rupiahs, in the other hand Bungus Teluk Kabung district has the lowest travel cost is 120,877 rupiahs. The high average travel cost to BBI Lubuk Minturun is determined by average visit per year per person. The highest consumer surplus is at Koto Tangah district zone attain 99,875.23 rupiahs and the lowest is Teluk Kabung district zone. Furthermore, the lowest average costs based on origin visit zone are Agam, Lima PuluhKota, and west Pasaman destination
\end{abstract}

\section{Abstrak}

Penelitian ini berfokus pada masyarakat tarik sosial ekonomi di agrowisata BBI Lubuk Minturun wilayah Sumatera Barat. Metode ini pendekatan ekonomi regional dengan analisis alat yang lokasi quotient, analisis Shift Share, dan metode biaya perjalanan untuk menentukan mengintegrasikan hubungan kegiatan ekonomi masyarakat di wilayah tersebut. Ini penelitian menunjukkan, pertama: Padang tarik wisata berpotensi sebagai pusat activitiy Nasional (PKN) di PP No: 50 tahun 2011 tentang masterplan pariwisata nasional termasuk di tujuan pariwisata nasional (DPN) bersama-sama dengan Bukittinggi. Selanjutnya, dalam masterplan pariwisata Sumatera Barat, Padang telah menjadi Provinsi wilayah tujuan wisata (DPP) dengan daerah tujuan strategis (KSPP) adalah Pesisir Selatan, Padang Pariaman dan daerah potensinya adalah kota Pariaman. Dalam kasus seperti DPN, DPP kota Padang memiliki potensi wisata yang luas, sekitar 169 destinasi pariwisata untuk menarik wisatawan asing dan nasional untuk mengunjungi dan menghabiskan waktu luang mereka. Kedua: zona kabupaten Kuranji memiliki biaya perjalanan tertinggi di luar kawasan Koto Tangah rata sebesar 170.783 rupiah, di sisi lain kabupaten Bungus Teluk Kabung memiliki biaya perjalanan terendah adalah 120.877 rupiah. Tinggi rata-rata biaya perjalanan ke BBI Lubuk Minturun ditentukan oleh rata-rata kunjungan per tahun per orang. Surplus konsumen tertinggi adalah di zona kabupaten Koto Tangah mencapai 99,875.23 rupiah dan terendah adalah zona kabupaten Teluk Kabung. Selain itu, biaya rata-rata terendah berdasarkan asal zona kunjungan yang Agam, Lima Puluh Kota, dan tujuan Pasaman barat

Keywords: agrotourism zone, tourism destination potential attraction, linkages on community economic and tourism activities zone 


\section{PENDAHULUAN}

Sektor ekonomi pariwisata merupakan instrument (powerfull vehicle) yang sangat kuat untuk mendorong pertumbuhan ekonomi dan menciptakan lapangan pekerjaan bagi suatu wilayah. Sektor ekonomi pariwisata baik langsung maupun tidak langsung telah memberikan sumbangan terhadap penciptaan lapangan kerja di Sumatera Barat yang mencapai $23,29 \%$ dari total lapangan kerja yang terbuka tahun 2011 sebesar 2.070.725 (BPS, Sakernas, 2011), 29,73\% dari total nilai PDRB Sumatera Barat tahun 2011 yang mencapai Rp 41.276.406,36. Mencapai $83,16 \%$ dari total eksport Sumatera Barat baik ekspor keluar negeri (Rp 11.230.197.18) maupun antar provinsi (Rp3.525.699,82). Diperkirakan peran ekonomi pariwisata ini akan terus meningkatkan pada masa yang akan datang.

Potensi pertumbuhan sector pariwisata di provinsi Sumatera Barat dapat dilihat dari jumlah kunjungan turis mancanegara dan nusantara yang datang setiap harinya. Jumlah kunjungan turis ke wilayah Sumatera Barat tahun 2012 mencapai 1.553 orang yang terdiri dari turis mancanegara sebanyak 42 orang dan turis nusantara sebanyak 1.511 orang. Total jumlah kunjungan turis ke wilayah Sumatera Barat itu baru sebesar $7,16 \%$ dari total kunjungan turis ke wilayah Sumatera yang mencapai 21.692 orang, dan mencapai 1,45\% dari jumlah total kunjungan turis ke Indonesia tahun 2012 ini. Sungguhpun demikian terdapat trend yang meningkat dalam jumlah kunjungan turis mancangera ke wilayah Sumatera Barat karena jumlah kunjungan turis mancanegara ini yang datang berkunjung ke wilayah Sumatera Barat tahun 2009 berjumlah 35 orang dan mengalami kenaikan menjadi 39 orang tahun 2010 dan terus meningkat menjadi 42 orang tahun 2012. Sedangkan rata-rata lama tinggal turis mancanegara di wilayah Sumatera Barat tahun 2011 pada hotel berbintang adalah 1,87 malam, masih jauh lebih rendah dari rata-rata lama tinggal turis mancanegara di hotel berbintang di wilayah Sumatera yang mencapai 3,4 malam. Rata-rata lama tinggal turis mancanegara pada hotel non bintang di wilayah Sumatera Barat tahun 2011 adalah
1,34 malam, sedangkan rata-rata Sumatera itu adalah sebesar 2,65 malam.

Hal ini bararti bahwa daya tarik obyek wisata dan wilayah destinasi wisata yang ada, belum mampu membuat wisatawan betah tinggal dan berlama-lama dalam kunjungannya ke wilayah Sumatera Barat. Untuk itu diperlukan peningkatan jumlah event-event di wilayah destinasi yang membuat waktu tinggal turis menjadi lebih lama di wilayah Sumatera Barat.

Pada sisi penawaran pariwisata, potensi pariwisata provinsi Sumatera Barat dapat dilihat dari keberadaan daya tarik wisata. Daya tarik wisata dapat dibedakan menjadi daya tarik wisata alamiah, budaya, lingkungan dan daya tarik event atau wisata minat khusus. Jumlah daya tarik alamiah pariwisata Sumatera Barat tahun 2013 adalah sebanyak 2.252 lokasi, jumlah daya tarik wisata budaya adalah sebanyak 9.667 obyek wisata, jumlah daya tarik wisata lingkungan adalah sebanyak 5.335 obyek dan jumlah daya tarik event adalah sebanyak 17.413 kegiatan (Dinas Budpar Provinsi Sumatera Barat, 2013). Besarnya potensi daya tarik wisata dan destinasi pariwisata Sumatera Barat ini ternyata belum diiringi oleh ketersediaan infrastruktur dasar dan sarana prasarana pariwisata yang cukup, seperti tempat parkir, rest area, WC, tempat belanja, bahkan system transportasi, moda kendaraan pengangkut turis, system jalan, dan lain sebagainya. Sehingga pergerakan wisatawan dari pusat kegiatan nasional, dan wilayah menuju wilayah destinasi masih menjadi hambatan yang membuat mobilitas wisatawan antar dan menuju wilayah destinasi masih rendah.

Potensi lain yang tidak kalah pentingnya adalah mengembangkan sub sector pariwisata seperti ekowisata, wisata religi, wisata alam liar dan agrowisata di wilayah Sumatera Barat. Potensi agrowisata didasarkan kepada potensi sector pertanian yang ada di wilayah Sumatera Barat. Salah satu unsur dari sektor pertanian yang saat ini belum tergarap secara optimal adalah agro wisata (agro tourism). Potensi agro wisata tersebut ditunjukkan dari keindahan alam pertanian dan produksi di sektor pertanian yang cukup berkembang. 
Sektor ekonomi pariwisata sudah menjadi andalan bagi daerah-daerah yang sedang tumbuh perekonomiannya dalam menopang kegiatan ekonomi lainnya yang menjadi basis untuk melakukan pembangunan ekonomi selama ini. Besarnya potensi daya tarik wisata yang terlihat dari potensi alamiah, budaya, lingkungan, ditambah dengan tingginya keinginan turis mancanegara untuk datang berkunjung merupakan suatu peluang dalam mengembangkan sector ekonomi pariwisata menuju kepada industry pariwisata di Sumatera Barat.

Tingginya minat kunjungan wisatawan baik domestic maupun asing ini, ternyata belum diiringi oleh lamanya tinggal dan besarnya belanja yang dilakukan oleh wisatawan ini. Hal ini terlihat dari rata-rata lama tinggal wisatawan pada hotel non bintang di Sumatera Barat itu baru 1,87 malam masih jauh dari rata-rata lama tinggal wisatawan Sumatera yang mencapai 2,65 malam, bahkan Indonesia mencapai 3,41 malam. Artinya, aktifitas kepariwisataan yang ada selama ini di wilayah Sumatera Barat, belum mampu menangkap economic rent yang muncul dari kegiatan wisatawan ini, hal ini terlihat dari masih rendahnya porsi ekonomi wisatawan ini dari nilai PDRB Sumatera Barat yang mencapai $29,73 \%$. Masih belum terbukanya kesempatan kerja bagi masyarakat local untuk memperoleh pekerjaan pada sector kepariwisataan ini, sehingga bagi masyarakat sendiri daya tarik untuk bekerja dan berbisnis pada sector ini masih rendah.

$\begin{array}{lcc}\begin{array}{c}\text { Persoalan } \\ \text { diselesaikan }\end{array} \text { dalam urgen untuk } & \text { pembangunan }\end{array}$
kepariwisataan itu adalah bagaimana mengaitkan aktifitas ekonomi masyarakat yang masih dominan itu dalam sector pertanian dalam arti luas, dengan kegiatan kepariwisataan yang dapat menambah daya tarik bagi wisatawan yang datang berkunjung ke wilayah Sumatera Barat. Aktifitas pertanian masyarakat Minangkabau yang kental dengan budaya agraris dan dijalin dengan nuansa keagamaan Islam, telah membawa daya tarik sendiri bagi kunjungan wisatawan. Praktek pertanian masyarakat Minangkabau secara tradisional maupun modern, tentunya akan menjadi paket kunjungan wisatawan yang menarik. Sampai saat ini belum ada destinasi wisata yang menawarkan konsep wisata agro ini di wilayah Sumatera Barat yang representative mewakili culture dan nilai-nilai masyarakat agraris yang kental dengan budaya Minangkabau dan kekhasan hasil bumi local Sumatera Barat baik dalam bentuk tanaman pangan, hortikultura, tanaman endemic, tanaman pharmacy, dan kegiatan pertanian lainnya dalam arti luas yang memberikan symbol terhadap kehidupan social ekonomi masyarakat Minangkabau dengan tatanan system matrilinealnya yang unik.

Oleh karena itu, diperlukan pengembangan satu destinasi wisata agro yang representative di Sumatera Barat untuk direncanakan dengan baik sehingga dapat mewakili keinginan untuk membangun kepariwisataan Sumatera Barat yang menarik bagi wisatawan yang dating berkunjung. Kawasan rintisan wisata agro yang sudah ditunjuk dan ditetapkan oleh pemerintah provinsi Sumatera Barat itu adalah kawasan agrowisata BBI Lubuak Minturun, Kota Padang.

Sehubungan dengan luasnya persoalan yang ada, maka dalam kegiatan ini dibatasi kepada persoalan sebagai berikut:

1) Bagaimana potensi pengembangan agrowisata BBI Lubuak Minturun dapat ditemukan sehingga mencapai nilai manfaat optimal ?

2) Bagaimana strategi pengembangan kawasan agrowisata BBI Lubuak Minturun dapat dilaksanakan, sehingga menjadi wilayah destinasi utama wisatawan mancanegara dan nusantara?

3) Bagaimana pengelolaan agrowisata BBI Lubuak Minturun dapat dilakukan sehingga dapat memberdayakan perekonomian masyarakat dan dapat mengembangkan

Hasil penelitian ini dapat digunakan oleh pemerintahan provinsi Sumatera Barat dalam mendisain kebijakan pengembangan kawasan agrowisata BBI Lubuk Minturun sebagai kawasan agrowisata di Sumatera Barat, terutama dalam mendisain arsitektur 
landscape dan pengelolaan kawasan agrowisata berbasis partisipasi masyarakat.

\section{METODOLOGI PENELITIAN}

Penelitian ini dilakukan pada kawasan agrowisata BBI Lubuk Minturun, kecamatan Koto Tangah, Kota Padang. Penelitian ini dilakukan dengan biaya dari Badan Perencanaan Pembangunan Daerah (Bappeda) provinsi Sumatera Barat yang dilaksanakan selama lebih kurnag 4 bulan yang dimulai pada bulan maret $2014 \mathrm{~s} / \mathrm{d}$ Agustus 2014.

Populasi penelitian ini adalah penduduk Kota Padang, dan sampel adalah wisatawan dan pelaku usaha pariwisata di kecamatan Koto Tangah terutama di kawasan BBI Lubuk Minturun. Sampel wisatawan berasal dari pengunjung yang dating ke kawasan wisata Lubuk Minturun dan sampel pelaku usaha wisatawan adalah pelaku usaha agrowisata yang bermukim usahanya di kawasan ini. Sedangkan informan kunci adalah seluruh dinas yang terkait dengan pengembangan kawasan agrowisata BBI Lubuk Minturun ini.

Teknik pengambilan sampel untuk wisatawan adalah dengan menggunakan teknik aksidental; siapa pengunjung wisata yang ketemu dijadikan sampel, sedangkan untuk pelaku usaha pariwisata dilakukan dengan total sampling.

Data yang digunakan dalam penelitian ini adalah data primer dan data sekunder. Data primer diambil dengan menggunakan teknik pengumpulan data dilakukan dengan wawancara, FGD, dan quisioner. Sedangkan data sekunder dilakukan dengan studi literature dari dokumen kepariwisataan yang ada pada dinas pariwisata Kota Padang dan Provinsi Sumatera Barat dan kantor BPS Kota padang.

Teknik analisis data yang dilakukan untuk mengambarkan potensi ekonomi yang tercermin dari keunggulan komparatif melalui pengujian nilai location quotient (LQ) dan keunggulan kompetitif perekonomian Kota Padang melalui pengujian nilai Shift Share Analisis (SSA)teknik LQ, SSA, Indeks Potensi destinasi, dan travel cost method.

\section{PEMBAHASAN}

\section{Potensi Sosial Ekonomi Masyarakat Sekitar Kawasan Agrowisata BBI Lubuk Minturun}

Kondisi sosial ekonomi masyarakat sekitar kawasan agrowisata BBI Lubuak Minturun dapat dijelaskan dari keadaan penduduk, mata pencaharian, aktifitas leisure time yang digunakan. Kawasan Agrowisata BBI Lubuak Minturun dengan luas 9,8 ha berada di ketinggian 50 meter di atas permukaan laut terletak di Kota Padang, khususnya pada wilayah kecamatan Koto Tangah. Kawasan kecamatan Koto Tangah ini merupakan kawasan yang sebagian besar wilayahnya berbatasan langsung dengan Kabupaten Solok dengan deretan pergunungan Bukit Barisan, temperature ratarata adalah $22^{0} \mathrm{C}$, berhawa sejuk sehingga wilayah ini merupakan daerah dataran tinggi yang sering digunakan untuk tujuan wisata agro oleh penduduk Kota Padang.

Kota Padang sebagai Pusat kegiatan nasional (PKN) dalam PP No: 50 Tahun 2011 tentang Rencana Induk Kepariwisataan Nasional termasuk kepada destinasi pariwisata nasional (DPN) bersama Kota Bukittinggi. Selanjutnya dalam Rencana Induk Kepariwisataan provinsi Sumatera Barat, maka Kota Padang juga telah menjadi wilayah destinasi pariwisata provinsi (DPP) dengan destinasi kawasan strategisnya (KSPP) adalah Pesisir Selatan, Padang Pariaman, serta Kawasan Potensialnya adalah Kota Pariaman. Sehingga sebagai DPN, DPP Kota Padang memiliki potensi kepariwisataan yang besar untuk dapat menarik kedatangan turis manca Negara maupun turis nusantara untuk datang dan berkunjung menggunakan waktu luangnya.

Di Kota Padang terdapat sebanyak 169 obyek wisata yang dapat dijadikan destinasi pariwisata, yang terdiri dari 25 obyek wisata alam, 36 obyek wisata bahari, 73 obyek wisata sejarah, 2 obyek wisata budaya, 24 obyek wisata belanja, dan 9 obyek wisata kuliner. Disamping itu, Kota Padang juga memiliki 2 obyek wisata event yang digelar secara teratur setiap tahunnya.

Daya tarik obyek wisata ini tentunya akan didukung oleh sejumlah factor dasar akomodasi, transportasi dan fasilitas belanja. 
Diantara factor dasar yang mendukung aktifitas pariwisata di Kota Padang ini, maka akan dilihat indek ketersediaan infrastruktur dasar yang mendukung kepariwisataan kota Padang.

Indek transportasi yang mendukung usaha perjalanan pariwisata di Kota Padang mencapai 145,42 yang dibentuk dari jumlah perusahaan biro perjalanan yang mencapai 65,57 , jumlah angkutan darat yang mencapai 32,57, jumlah angkutan taxi dengan indek mencapai 47,28. Semua angka indek ini jika dibandingkan dengan kabupaten dan kota lainnya di Sumatera Barat, maka Kota Padang memiliki angka indek ketersediaan transportasi yang paling tinggi.

Indeks akomodasi pariwisata Kota Padang adalah mencapai 120,07 yang terdiri dari restoran, café, homestay, hotel berbintang, dan hotel non bintang, angka indeks ini paling tinggi diantara kabupaten dan Kota lainnya di Sumatera Barat.

Daya tarik obyek wisata ini dilengkapi dengan fasilitas penginapan berupa hotel berbintang sebanyak 18 hotel dan tidak berbintang sebanyak 47 buah dengan jumlah kamar sebanyak 2. 295 kamar. Jumlah tamu asing yang datang menginap di hotel berbintang yang ada adalah sebanyak 15.609 setiap tahunnya dan tamu asing yang menginap pada hotel non bintang adalah mencapai 2.262. sehingga jumlah tamu asing yang dating menginap pada hotel di Kota padang adalah sebanyak 17.871 orang atau sebesar 33,28\% dari total jumlah kunjungan turis ke wilayah Kota Padang tahun 2012. Pada sisi lain, jumlah tamu domestic yang dating menginap pada hotel berbintang adalah sebanyak 207.032 orang atau sebesar $67,37 \%$ dari jumlah tamu domestic yang ada dan jumlah yang menginap di hotel non bintang adalah sebanyak 100.228 orang atau sebesar $32,63 \%$ dari total tamu domestic yang dating menginap di Kota Padang.

Pada tabel 1 di bawah, memperlihatkan fasilitas akomodasi yang mendukung kegiatan pariwisata di Sumatera Barat, terlihat bahwa Kota Padang dan Kota Bukittinggi memiliki indeks fasilitas akomodasi yang tertinggi masing-masing secara berturut turut mencapai 120,07 dan 81,46 , sedangkan wilayah destinasi pariwisata lain masih memiliki indeks fasilitas akomodasi yang relative rendah. Wilayah DPP Sawahlunto mencapai 21,72 dan DPP Padangpanjang mencapai 10,76. Tentunya, untuk mendukung peningkatan perekonomian dari sub sector pariwisata ini, maka fasilitas akamodasi pariwisata ini perlu dibenahi, agar rata-rata lama tinggal wisatawan di daerah destinasi pariwisata Sumatera Barat dapat meningkat.

Tabel 1. Indeks Fasilitas Akomodasi Pariwisata Kota Padang Relatif terhadap Kabupaten dan Kota Lain di Sumatera Barat

\begin{tabular}{|c|c|c|c|c|c|c|c|}
\hline No & Kabupaten/Kota & Restoran & Cafe & Homestay & $\begin{array}{l}\text { Hotel } \\
\text { Bintang }\end{array}$ & $\begin{array}{l}\text { Hotel } \\
\text { Non } \\
\text { Bintang }\end{array}$ & $\begin{array}{l}\text { Indeks } \\
\text { Akamodasi } \\
\text { Pariwisata }\end{array}$ \\
\hline 1 & Kota Padang & 19.54 & 30.14 & 6.72 & 37 & 26.67 & 120.07 \\
\hline 2 & $\begin{array}{l}\text { Kab. Pesisir } \\
\text { Selatan }\end{array}$ & 2.79 & 5.48 & 0.00 & 0 & 5.42 & 13.69 \\
\hline 3 & $\begin{array}{l}\text { Kab.Padang } \\
\text { Pariaman }\end{array}$ & 8.65 & 2.74 & 2.99 & 0 & 1.00 & 15.38 \\
\hline 4 & Kab. Solok & & & & & & \\
\hline & Selatan & 3.28 & 1.37 & 6.72 & 1.5 & 0.62 & 13.49 \\
\hline 5 & Kota Pariaman & 0.00 & 0.00 & 0.00 & 0 & 2.71 & 2.71 \\
\hline 6 & Kota Bukittinggi & 12.42 & 5.48 & 3.73 & 41.56 & 18.27 & 81.46 \\
\hline 7 & Kab. Agam & 16.75 & 2.74 & 9.70 & 10.83 & 7.34 & 47.36 \\
\hline 8 & Kab. Pasaman & 2.30 & 5.48 & 11.94 & 0 & 4.77 & 24.50 \\
\hline 9 & Kab. Pasaman & & & & & & \\
\hline & Barat & 5.30 & 12.33 & 5.22 & 0 & 6.13 & 28.99 \\
\hline 10 & Kab. 50 Kota & 3.21 & 2.74 & 2.99 & 0 & 0.71 & 9.64 \\
\hline 11 & Kota & 5.72 & 17.81 & 1.49 & 0 & 5.45 & 30.48 \\
\hline
\end{tabular}




\begin{tabular}{|c|c|c|c|c|c|c|c|}
\hline \multirow{3}{*}{12} & \multicolumn{7}{|l|}{ Payakumbuh } \\
\hline & \multicolumn{7}{|l|}{ Kota } \\
\hline & Padangpanjang & 2.02 & 0.00 & 5.97 & 0 & 2.77 & 10.76 \\
\hline 13 & Kab. Tanah Datar & 1.05 & 0.00 & 4.48 & 4.39 & 2.39 & 12.30 \\
\hline 14 & Kota Solok & 0.56 & 0.00 & 1.49 & 0.00 & 3.36 & 5.41 \\
\hline 15 & Kota Sawahlunto & 2.86 & 0.00 & 30.60 & 3.33 & 3.98 & 40.77 \\
\hline 16 & Kab. Solok & 7.26 & 2.74 & 4.48 & 0.00 & 1.92 & 16.39 \\
\hline 17 & Kab. Sijunjung & 6.28 & 10.96 & 0.00 & 1.39 & 3.09 & 21.72 \\
\hline 18 & Kab. & & & & & & \\
\hline \multirow{3}{*}{19} & Dharmasraya & 0.00 & 0.00 & 1.49 & 0.00 & 3.39 & 4.88 \\
\hline & Kab. Kep. & & & & & & \\
\hline & Mentawai & 0.00 & 0.00 & 0.00 & 0.00 & 0.00 & 0 \\
\hline
\end{tabular}

Sumber: Hasil Analisis (data diolah), 2012

Berdasarkan kepada tabel 2 di bawah, perekonomian Kota Padang memiliki keunggulan pada sector industry pengolahan, perdagangan dan hotel, sector pengangkutan dan komunikasi serta sector keuangan dan jasa perusahaan. Hal ini ditunjukkan oleh nilai LQ yang lebih besar dari satu. Artinya perekonomian Kota Padang berbasis selama ini kepada sector industry pengolahan terutama sub sector pengalian, sector perdagangan dan hotel, terutama sub sector perdagangan besar dan eceran dan sub sector hotel yang memiliki nilai LQ lebih besar dari satu pada kedua titik tahun analisis.

Peningkatan Keikutsertaan Aktifitas Ekonomi Masyarakat secara Terintegrasi di Sekitar Kawasan

Tabel.2.Potensi Ekonomi Menurut Nilai PDRB Kota Padang

\begin{tabular}{|c|c|c|c|c|c|c|}
\hline No & Lapangan Usaha & 2010 & 2012 & LQ 2010 & LQ 2012 & SSA \\
\hline \multirow[t]{6}{*}{1} & Pertanian & 612.53 & 680.47 & 0.22 & 0.22 & 0.02 \\
\hline & a. Tanaman Pangan & 168.27 & 185.43 & 0.12 & 0.12 & 0.03 \\
\hline & b. Perkebunan & 5.57 & 6.16 & 0.01 & 0.01 & 0.02 \\
\hline & c. Peternakan & 88.33 & 94.99 & 0.39 & 0.38 & 0.05 \\
\hline & d. Kehutanan & 33.46 & 3.42 & 0.22 & 0.02 & 8.90 \\
\hline & e. Perikanan & 347.02 & 390.46 & 1.10 & 1.12 & 0.01 \\
\hline \multirow[t]{2}{*}{2} & $\begin{array}{l}\text { Pertambangan dan Pengalian } \\
\text { a Pertambangan }\end{array}$ & 185.32 & 211.78 & 0.50 & 0.52 & -0.01 \\
\hline & b. Penggalian & 185.32 & 211.78 & 0.60 & 0.63 & -0.02 \\
\hline \multirow[t]{2}{*}{3} & $\begin{array}{l}\text { Industri Pengolahan } \\
\text { a. Industri migas }\end{array}$ & 1938.43 & 2119.22 & 1.31 & 1.31 & 0.03 \\
\hline & b. Industri tanpa migas & 1938.43 & 2119.22 & 1.31 & 1.31 & 0.01 \\
\hline \multirow[t]{3}{*}{4} & Listrik, Gas dan Air Bersih & 214.89 & 241.01 & 1.57 & 1.61 & 0.01 \\
\hline & $\begin{array}{l}\text { a. Listrik } \\
\text { b. Gas }\end{array}$ & 195.41 & 219.44 & 1.59 & 1.63 & 0.01 \\
\hline & c. Air bersih & 19.47 & 21.57 & 1.46 & 1.47 & 0.02 \\
\hline 5 & Bangunan & 517.21 & 613.49 & 0.81 & 0.82 & -0.04 \\
\hline 6 & Perdagangan, Hotel dan Restoran & 2544.65 & 2839.12 & 1.19 & 1.15 & $\mathbf{0 . 0 1}$ \\
\hline
\end{tabular}




\begin{tabular}{lrrrrr}
\hline a. Perdagangan besar dan eceran & 2499.14 & 2789.26 & 1.21 & 1.17 & 0.01 \\
b. Hotel & 26.47 & 28.58 & 1.25 & 1.18 & 0.04 \\
c. Restoran & 19.04 & 21.29 & 0.33 & 0.32 & 0.01 \\
Pengangkutan dan Komunikasi & $\mathbf{3 0 2 0 . 0 7}$ & $\mathbf{3 5 6 1 . 5 9}$ & $\mathbf{1 . 6 9}$ & $\mathbf{1 . 6 8}$ & $\mathbf{- 0 . 0 3}$ \\
a. Pengangkutan & 1910.83 & 2124.23 & 1.46 & 1.38 & 0.02 \\
$\quad$ 1. Kereta Api & 30.58 & 32.81 & 3.20 & 3.31 & 0.05 \\
2. Jalan Raya & 1125.67 & 1250.53 & 1.30 & 1.22 & 0.02 \\
$\quad$ 3. Angkutan Laut & 274.90 & 297.16 & 3.32 & 3.37 & 0.04 \\
$\quad$ 4. Angkutan Sungai & 60.75 & 63.56 & 2.46 & 2.41 & 0.07 \\
$\quad$ 5. Angkutan Udara & & & & & \\
$\quad$ 6. Jasa Penunjang angkutan & 418.93 & 480.18 & 3.02 & 2.99 & -0.01 \\
b. Komunikasi & 1118.24 & 1437.36 & 2.33 & 2.46 & -0.10 \\
Keuangan, persewaan dan Jasa & $\mathbf{9 7 7 . 1 8}$ & $\mathbf{1 1 3 2 . 5 1}$ & $\mathbf{1 . 5 7}$ & $\mathbf{1 . 6 3}$ & $\mathbf{- 0 . 0 2}$ \\
Perusahaan & & & & & \\
a. Bank & 351.89 & 406.81 & 1.61 & 1.62 & -0.02 \\
b. Lembaga keuangan non bank & 253.72 & 298.03 & 1.68 & 1.75 & -0.03 \\
c. Sewa Bangunan & 324.44 & 373.78 & 1.38 & 1.47 & -0.01 \\
d. Jasa Perusahaan & 47.13 & 53.88 & 2.64 & 2.78 & -0.01 \\
Jasa Jasa & $\mathbf{2 0 0 2 . 3 2}$ & $\mathbf{2 2 3 8 . 1 8}$ & $\mathbf{0 . 9 9}$ & $\mathbf{0 . 9 5}$ & $\mathbf{0 . 0 1}$ \\
a. Pemerintahan Umum & 982.19 & 1100.16 & 0.73 & 0.69 & 0.01 \\
b. Swasta & & & & & \\
$\quad$ 1. Sosial Kemasyarakatan & 1020.13 & 1138.02 & 1.53 & 1.49 & 0.01 \\
2. Hiburan dan Rekreasi & 439.74 & 507.18 & 1.74 & 1.75 & -0.01 \\
$\quad$ 3. Perorangan & 180.25 & 197.60 & 2.46 & 2.28 & 0.03 \\
$\quad$ Rumahtangga & & & & & \\
Total PDRB & 400.14 & 433.25 & 1.18 & 1.11 & 0.04 \\
\hline
\end{tabular}

Prinsip dasar metoda TCM adalah teori permintaan konsumen dimana nilai yang diberikan seseorang pada lingkungan (atribut yang tidak dipasarkan) dapat disimpulkan dari biaya yang dikeluarkan ke lokasi yang dikunjungi. Biaya konsumsi layanan jasa lingkungan ini dapat berupa biaya transportasi, biaya masuk, pengeluaran ditempat rekreasi, dan biaya korbanan waktu yang dikeluarkan oleh seseorang wisatawan. Asumsi mendasar dari model TCM adalah perjalanan dan tempat rekreasi yang bersifat komplementer lemah (weak complementer), sehingga nilai tempat rekreasi dapat diukur dari biaya perjalan. Dengan demikian, jika biaya perjalanan ke tempat rekreasi sangat mahal, jumlah pengunjung hampir tidak ada, maka utilitas marginal untuk meningkatkan kualitas lingkungan tempat rekreasi juga nol.

Konsep surplus konsumen merupakan isu sentral dalam TCM. TCM ini menunjukkan seberapa besar seseorang menilai suatu tempat wisata yang didasarkan kepada kunjungan yang dilakukannya. Ada tiga pendekatan TCM yang dapat digunakan yakni: (1). Individual Travel Cost Method (ICTM), (2). Zone Travel Cost Method (ZTCM), (3). Random Utiliti Model (RUM). Pada semua metode ini fungsi trip perjalanan ke lokasi rekreasi ditentukan oleh jumlah kunjungan ke lokasi pariwisata dipengaruhi oleh total biaya perjalan, jumlah penduduk dan variable social ekonomi lainnya yang berkaitan dengan pemanfaatan waktu luang seseorang seperti tingkat pendidikan, pendapatan rata-rata dan lain sebagainya.

Pada kasus kunjungan wisatawan ke destinasi agrowisata BBI Lubuk Minturun digunakan metode zone travel cost method (ZTCM) untuk zona kabupaten dan kota di Sumatera Barat dan untuk kunjungan turis yang berasal dari Kota Padang digunakan metoda Indvidual travel cost method (ITCM).

Data untuk menganalisis digunakan data sekunder, terutama jarak ke lokasi BBI Lubuk Minturun, waktu tempuh, rata-rata 
biaya perjalanan dan rata-rata jumlah kunjungan ke lokasi BBI Lubuk Minturun. Khusus untuk data jumlah kunjungan digunakan asumsi bahwa jumlah kunjungan

Tabel 3. Data Hipotesis untuk Menghitung Persamaan Biaya Perjalanan Wisata Agro Ke BBI Lubuk Minturun

\begin{tabular}{llr}
\hline Zona (kecamatan) & $\begin{array}{l}\text { Jarak ke BB } \\
\text { LB Minturu } \\
(\mathbf{K m})\end{array}$ \\
\cline { 2 - 2 } & & 25 \\
Bungus TK & 20 \\
LB Kilangan & 22 \\
LB Begalung & 19 \\
Padang Selatan & 1 \\
Padang Timur & 16 \\
Padang Barat & 1 \\
Padang Utara & 10 \\
Nanggalo & \\
Kuranji & \\
Pauh & \\
Koto Tangah & \\
\hline
\end{tabular}

Tabel 3 di atas memperlihatkan bahwa rata-rata biaya perjalan sangat ditentukan oleh waktu tempuh menuju lokasi agrowisata BBI Lubuk Minturun, semakin lama waktu tempuh semakin tinggi biaya rata-rata perjalanan menuju lokasi agrowisata BBI Lubuk Minturun. Zona lokasi yang paling jauh adalah wisatawan yang berasal dari zona kecamatan Bungus Teluk Kabung yang mencapai waktu tempuh lebih kurang satu jam atau 60 menit. Setelah memperhitungkan operasional, biaya korbanan dan retribusi, maka biaya rata-rata perjalan ke lokasi agrowisata BBI Lubuk Minturun adalah sebesar Rp 123.000,- sedangkan pada waktu tempuh terkecil adalah pada zona Koto Tangah itu sendiri yang hanya membutuhkan waktu lebih kurang 10 menit, sehingga ratarata biaya perjalanan adalah sebesar $\mathrm{Rp}$ 20.500,-/trip/orang.

Berdasarkan data hipotesis tersebut diatas, lalu diregresikan antara rata-rata biaya data hipotesis adalah 5\% dari jumlah penduduk pada setiap kecamatan yang ada di Kota Padang.

\begin{tabular}{|c|c|c|}
\hline $\begin{array}{l}\text { Waktu } \\
\text { Tempuh } \\
\text { (Menit) } \\
\end{array}$ & $\begin{array}{l}\text { Rata-rata } \\
\text { Biaya } \\
\text { Perjalanan }\end{array}$ & $\begin{array}{l}\text { Rata-rata } \\
\text { kunjungan } \\
\text { perorang/tahun }\end{array}$ \\
\hline & (Rp) & \\
\hline 60 & 123000 & 1168 \\
\hline 50 & 102500 & 2512 \\
\hline 55 & 112750 & 5479 \\
\hline 45 & 92250 & 2916 \\
\hline 40 & 82000 & 3899 \\
\hline 35 & 71750 & 2320 \\
\hline 30 & 61500 & 3486 \\
\hline 25 & 51250 & 2912 \\
\hline 20 & 41000 & 6546 \\
\hline 27 & 55350 & 3088 \\
\hline 10 & 20500 & 8389 \\
\hline
\end{tabular}

perjalanan dengan rata-rata kunjungan perorang pertahun, sehingga metoda OLS menghasilkan persamaan biaya perjalanan sebagai berikut:

$$
\begin{aligned}
& \mathrm{TC}=110037,9-9,2836 \mathrm{Vj}+\varepsilon_{\mathrm{i}} \\
& \begin{array}{l}
(6,3477) \quad(2,3409) \\
\mathrm{R}^{2}
\end{array}=0,3784 \\
& \mathrm{AIC}=23,3629 \\
& \mathrm{SIC}=23,4352
\end{aligned}
$$

Berdasarkan kepada persamaan di atas, maka dapat dikatakan bahwa apabila total biaya perjalanan menuju lokasi BBI Lubuk Minturun menurun sebesar 1\%, maka jumlah kunjungan ke obyek wisata BBI Lubuak Minturun ini akan mengalami kenaikan sebesar 9, 28\%. Dari persamaan total biaya perjalanan menuju lokasi obyek wisata BBI Lubuk Minturun, maka dapat dihitung surplus konsumen untuk setiap kecamatan yang ada. 
Tabel 4. Total Biaya Perjalanan Surplus Konsumen Individu dan Menurut Zona asal kedatangan Wisatawan

\begin{tabular}{lccc} 
Zona (Kecamatan) & $\begin{array}{c}\text { Total Biaya } \\
\text { Perjalanan ke } \\
\text { Kawasan BBI } \\
\text { LB Minturun } \\
\text { (Rp) }\end{array}$ & $\begin{array}{c}\text { Surplus } \\
\text { Konsumen per } \\
\text { Individual } \\
(\mathbf{R p )}\end{array}$ & $\begin{array}{c}\text { Surplus } \\
\text { Konsumen } \\
\text { Setiap Zona } \\
(\mathbf{R p})\end{array}$ \\
\hline TK & 120,877 & $66,367.24$ & $1,550,338,637$ \\
ngan & 133,353 & $72,605.48$ & $3,648,352,974$ \\
Selatan & 160,885 & $86,371.20$ & $9,464,902,037$ \\
Timur & 137,098 & $74,477.96$ & $4,343,554,403$ \\
Barat & 146,225 & $79,041.16$ & $6,164,341,352$ \\
Utara & 131,573 & $71,715.07$ & $3,328,368,029$ \\
& 142,392 & $77,124.84$ & $5,377,838,259$ \\
& 137,058 & $74,457.54$ & $4,335,811,479$ \\
& 170,783 & $91,320.23$ & $11,955,278,990$ \\
nalung & 138,692 & $75,274.88$ & $4,648,599,977$ \\
& 187,893 & $99,875.23$ & $16,758,164,409$ \\
\hline
\end{tabular}

Sumber: Hasil Penelitian (data diolah), 2014

Tabel 4 di atas memperlihatkan bahwa total biaya perjalanan ke kawasan agrowisata BBI LB Minturun, dimana zona Kecamatan Kuranji memiliki total rata-rata biaya perjalanan yang paling tinggi di luar kecamatan Koto Tangah sebesar Rp 170.783,sedangkan zona kecamatan Bungus Teluk Kabung yang paling rendah yakni sebesar Rp
120.877,- Tingginya rata-rata biaya perjalan ke kawasan BBI Lubuk Minturun ini ditentukan oleh rata-rata kunjungan perorang pertahun. Jika rata-rata kunjungan tinggi, maka biaya perjalalan akan rendah, tetapi sebaliknya apabila rata-rata kunjungan rendah, maka biaya rata-rata perjalanan akan lebih kecil.

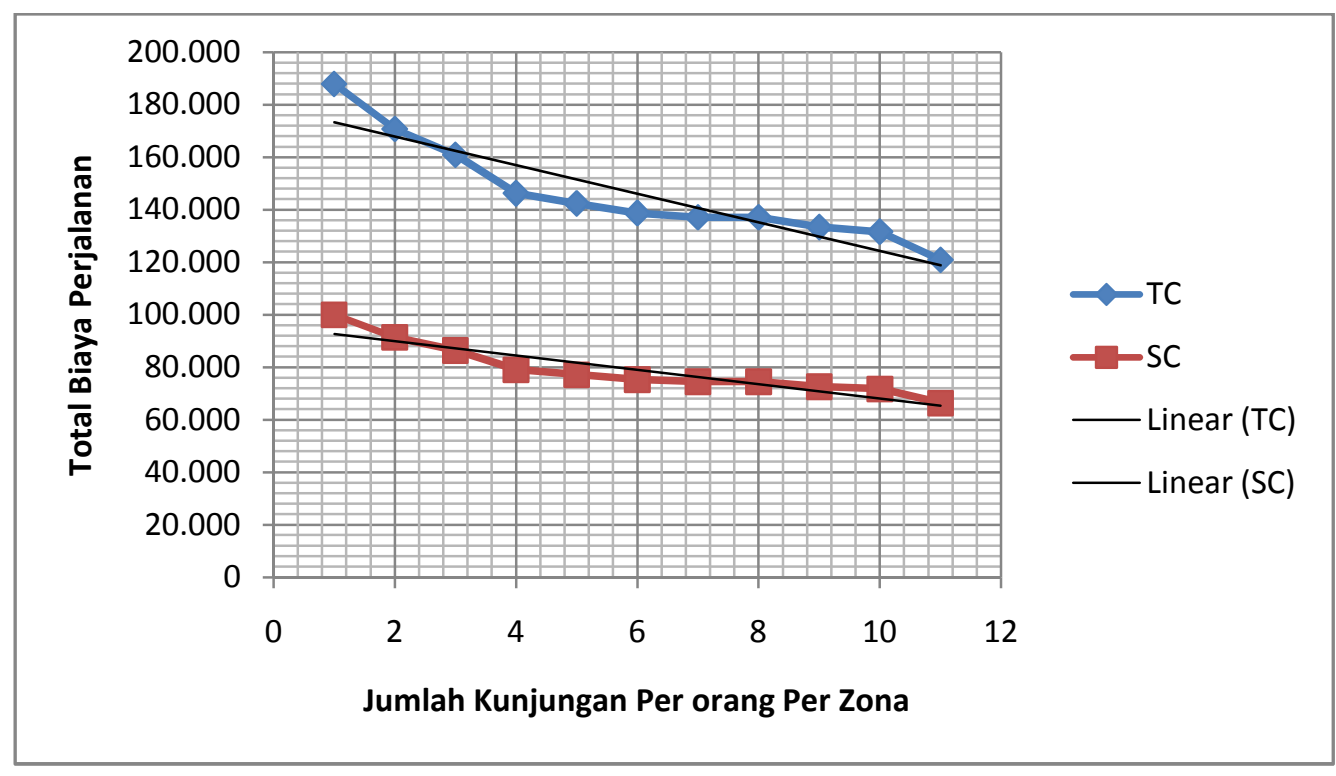

Gambar 1. Surplus Konsumen, Total Biaya Perjalanan Menurut Zona Kecamatan Pada Kunjungan Agrowisata BBI Lubuk Minturun 
Surplus konsumen per individual menurut zona kecamatan di Kota Padang juga dapat dijelaskan sebagaimana diinformasikan dalam tabel di atas. Semakin tinggi surplus konsumen yang diperoleh, maka semakin tinggi jumlah kunjungan yang orang yang dating ke obyek wisata BBI Lubuk Minturun. Nilai Surplus konsumen yang paling tinggi terdapat pada zona kecamatan Koto Tangah sendiri yang mencapai $\mathrm{Rp} 99.875,23$,- dan yang paling rendah adalah zona kecamatan bungus Teluk Kabung. Semakin tinggi nilai surplus konsumen yang akan diperoleh, maka semakin tinggi angka kunjungan ke lokasi agrowisata BBI Lubuk Minturun ini. sehingga dapat dikatakan Peluang wisatawan yang akan datang menikmati keuntungan dari nilai wisata agro BBI Lubuk Minturun akan diperoleh oleh zona yang berdekatan dengan keberadaan lokasi agrowisata BBI Lubuk Minturun. Zona Kecamatan Bungus Teluk Kabung memiliki nilai surplus konsumen yang mencapai Rp 66.367,24. Rendahnya surplus konsumen dari zona Bungus Teluk Kabung tentunya akan mempengaruhi jumlah perjalanan wisatawan menuju lokasi agrowisata BBI Lubuk Minturun. Berikut ini digambarkan kondisi relative surplus konsumen dan biaya rata-rata setiap zona di sekitar kawasan agrowisata BBI Lubuk Minturun.

Gambar 1 di atas memberikan informasi bahwa terdapat urutan zona kecamatan yang memberikan nilai surplus konsumen yang tinggi yakni secara berurutan adalah:

1. Zona Koto Tangah

2. Zona Kuranji

3. Zona Lubuk Begalung

4. Zona Padang Timur

5. Zona Padang Utara

6. Zona Pauh

7. Zona Padang Selatan

8. Zona Nanggalo

9. Zona Lubuk Kilangan

10. Zona Padang Barat

11. Zona Bungus Teluk Kabung
Semakin terletak pada urutan di atas, maka semakin besar surplus konsumen dalam memanfaatkan kawasan agrowisata BBI Lubuk Minturun, sehingga zona yang tertarik untuk memberikan jumlah pengunjung yang paling tinggi adalah kecamatan Koto Tangah sendiri, Zona Kuranji yang merupakan wilayah kecamatan terdekat dengan lokasi kawasan agrowisata BBI Lubuk Minturun di susul oleh zona Lubuk Bagalung dan Padang Timur dan seterusnya.

Gambar 2. di bawah memperlihatkan urutan Zona Kecamatan yang memiliki nilai Surplus Konsumen yang paling tinggi dalam memanfaatkan nilai Kawasan agrowisata BBI Lubuk Minturun Kota Padang. Semakin tinggi nilai surplus konsumennya, maka semakin tinggi peluang kunjungan turis yang akan mendatangi kawasan agrowisata BBI Lubuk Minturun. Sehingga pada gambar di atas terlihat beberapa zona yang menjadi basis untuk kedatangan wisatawan di sekitar kawasan agrowisata BBI Lubuk Minturun.

Selanjutnya, untuk penghitungan surplus konsumen kunjungan wisatawan dari zona kabupaten dan Kota yang ada di Sumatera Barat, digunakan data jarak kabupaten dan kota ke lokasi agrowisata BBI Lubuk Minturun, waktu tempuh yang dipakai dari kabupaten dan kota menuju lokasi BBI Lubuk minturun, rata-rata biaya perjalanan per trip/tahun dan rata-rata kunjungan perorang pertahun ke lokasi agrowisata BBI Lubuk Minturun. Semua data ini digunakan untuk menghitung nilai koefisien dari variable kunjungan wisatawan dan rata-rata biaya yang dikeluarkan dalam satu kali perjalanan. Nilai koofisien dari variable yang diregresikan digunakan untuk menghitung nilai surplus konsumen yang diperoleh oleh setiap zona dalam melakukan perjalanan wisata ke lokasi agrowisata BBI Lubuk Minturun. Hasil regresi dapat dikemukakan sebagai berikut:

$\mathrm{TC}=2072736-0,458957 \mathrm{JWisata}+\varepsilon_{\mathrm{i}}$ $(6,7309) \quad(1,8086)$

$\mathrm{R}^{2} \quad=0,1613$

AIC $=30,94$

SIC $=31,04$ 


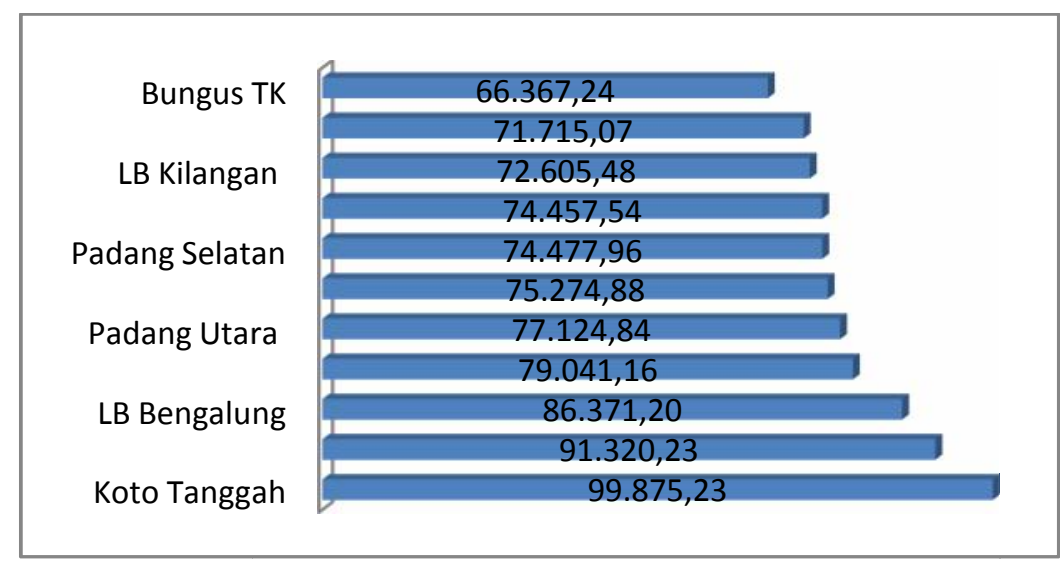

Gambar 2. Nilai Surplus Konsumsen Kawasan Agrowisata BBI Lubuk Minturun di Kota Padang

Berdasarkan hasil dan persamaan regresi di atas, maka dapat diinterpretasikan bahwa apabila rata rata biaya perjalanan menuju lokasi agrowisata BBI Lubuk Minturun turun 1\%, maka jumlah kunjungan wisata ke kawasan agrowisata BBI Lubuk Minturun akan mengalami kenaikan sebesar $1,81 \%$. Dari persamaan total biaya perjalanan menuju lokasi obyek wisata BBI Lubuk Minturun, maka dapat dihitung surplus konsumen untuk setiap kabupaten dan kota yang ada.

Tabel 5 di bawah memperlihatkan bahwa total biaya perjalanan calon wisatawan ke kawasan BBI Lubuk Minturun menurut

Tabel 5. Total Biaya Perjalanan Surplus Konsumen Individu dan Menurut Zona asal kedatangan Wisatawan

\begin{tabular}{lrrr}
\hline Zona (Kabupaten dan Kota) & $\begin{array}{c}\text { Total Biaya Perjalanan ke } \\
\text { Kawasan BBI LB } \\
\text { Minturun (Rp) }\end{array}$ & $\begin{array}{c}\text { Surplus Konsumen } \\
\text { per Individual(Rp) }\end{array}$ & $\begin{array}{c}\text { Surplus Konsumen } \\
\text { Setiap Zona(Rp) }\end{array}$ \\
\hline Kepulauan Mentawai & $3,997,500$ & $2,264,508$ & $177,788,818,198$ \\
Pesisir Selatan & 947,100 & $2,265,771$ & $991,587,546,096$ \\
Solok & 688,800 & $2,265,481$ & $804,420,138,329$ \\
Sijunjung & $1,660,500$ & $2,264,962$ & $469,920,693,176$ \\
Tanah Datar & $1,254,600$ & $2,265,438$ & $777,024,961,193$ \\
Padang Pariaman & 885,600 & $2,265,628$ & $899,189,170,217$ \\
Agam & $1,402,200$ & $2,265,863$ & $1,050,723,648,050$ \\
Lima Puluh Kota & $3,751,500$ & $2,265,484$ & $806,349,127,540$ \\
Pasaman & $2,066,400$ & $2,265,143$ & $586,511,150,955$ \\
Solok Selatan & $4,391,100$ & $2,264,754$ & $336,173,328,016$ \\
Dharmasraya & $2,865,900$ & $2,264,931$ & $449,846,943,835$ \\
Pasaman Barat & $3,357,900$ & $2,265,556$ & $853,090,704,837$ \\
Padang & 196,800 & $2,267,236$ & $1,936,981,590,915$ \\
Kota Solok & 787,200 & $2,264,447$ & $138,475,484,544$ \\
Sawahlunto & $1,168,500$ & $2,264,437$ & $131,491,299,230$ \\
Padangpanjang & 885,600 & $2,264,402$ & $109,114,727,920$ \\
Bukittinggi & $1,119,300$ & $2,264,635$ & $259,108,171,578$ \\
Payakumbuh & $2,595,300$ & $2,264,654$ & $271,627,138,114$ \\
Kota Pariaman & 688,800 & $2,264,517$ & $183,131,464,272$ \\
\hline
\end{tabular}

zona kabupaten dan kota di Sumatera Barat. Zona asal kunjungan yang memiliki rata-rata biaya yang paling kecil adalah pada zona destinasi utama pariwisata provinsi yakni Kota Padang, Kabupaten Pesisir Selatan, Kabupaten Padang Pariaman. Sedangkan zona asal kunjungan yang lebih rendah biaya ratarata keduanya adalah wilayah destinasi Kabupaten Agam, Lima Puluh Kota, Pasaman Barat. Di susul oleh zona destinasi pariwisata kabupaten Solok, Tanah Datar, Sijunjung dan Dharmasraya. Selebihnya relative tinggi biaya rata-rata perjalanan menuju lokasi BBI Lubuk Minturun. 
Gambar 3 di bawah menjelaskan bahwa biaya rata-rata perjalanan menuju lokasi agrowisata Lubuk Minturun berbanding lurus dengan nilai surplus konsumen dari lokasi wisata BBI Lubuk Minturun. Artinya, semakin rendah biaya rata-rata semakin besar jumlah kunjungan yang datang ke lokasi.

Biaya-rata-rata yang paling rendah adalah berada pada zona kota Padang yang hanya mencapai Rp 196.800,- sedangkan biaya totalnya mencapai Rp 1.184.060,- per orang pertahun. Sedangkan surplus konsumen yang diperoleh oleh zona Kota Padang ini adalah sebesar Rp 2.267.236 pertahun. Disusul oleh kabupaten Agam total biaya perjalanan kunjungan adalah sebesar $\mathrm{Rp}$ 1.402.200 atau Rp 116.850 perorang/bulan sedangkan surplus konsumennya mencapai Rp 2.265.863 per individu/tahun, atau hanya sekitar Rp 188.821 perorang/bulan dan nilai consumer surplus untuk wilayah kabupaten Agam adalah sebesar Rp 1.050 milyar pertahun. Dengan demikian pengunjung wisata yang berasal dari kabupaten Agam merupakan pengunjung yang potensial bagi destinasi agrowisata BBI Lubuk Minturun, disamping Kota Padang itu sendiri. Tempat ketiga diduduki oleh kabupaten Pesisir Selatan dengan surplus consumer mencapai Rp 991 milyar pertahun Padang Pariaman mencapai Rp 899 milyat per tahun. Wilayah mana yang menjadi daerah penyangga kunjungan wisata ke BBI Lubuk Minturun dapat dilihat pada gambar di bawah ini.

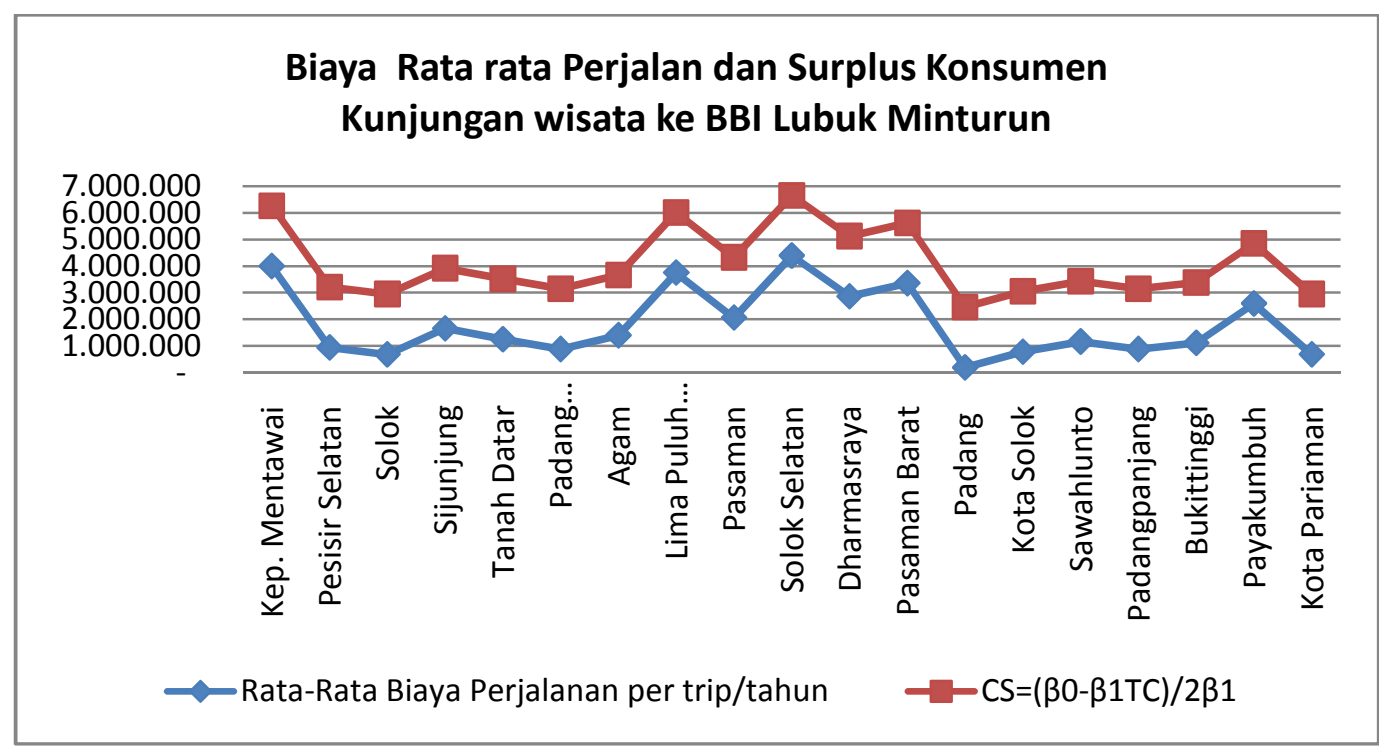

Gambar 3. Perbandingan Grafik Biaya Rata-Rata Perjalanan dan Surplus Konsumen Lokasi Agriwisata BBI Lubuk Minturun

Gambar 4. di bawah memperlihatkan rangking jumlah surplus konsumen yang diperoleh oleh pengunjung wisatawan yang berasal dari wilayah kabupaten dan kota yang ada di Sumatera Barat. Kota Padang Panjang menempati urutan paling rendah bersama 
Kota Sawahlunto dan Kota Solok. Hal ini disebabkan oleh rendahnya jumlah kunjungan turis. Jumlah surplus konsumen yang diperoleh oleh wisatawan dari Kota Padang Panjang adalah sebesar Rp 2.264.402 pertahun atau Rp 188.700 perorang/perbulan. Kota Sawahlunto surplus konsumennya mencapai Rp 2.264437 orang/pertahun atau sebesar Rp 188.703 orang per bulan.

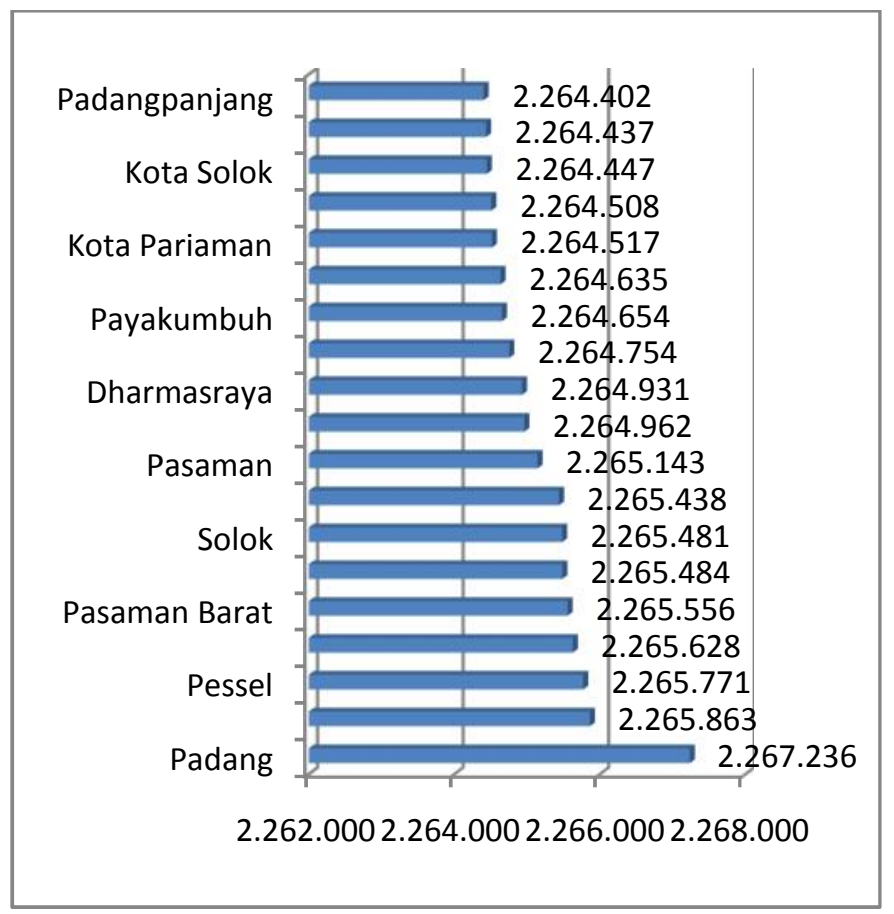

Gambar 4. Nilai Suprlus Konsumsen Kawasan Agrowisata BBI Lubuk Minturun Setiap Kabupaten dan Kota di Sumatera Barat

\section{KESIMPULAN}

Berdasarkan kepada permasalahan dan pertanyaan penelitian yang telah dijaukan, serta dilakukan pembahasan, maka dapat disimpulkan sebagai berikut:

1. Potensi daya tarik wisata Kota Padang sebagai Pusat kegiatan nasional (PKN) dalam PP No: 50 Tahun 2011 tentang Rencana Induk Kepariwisataan Nasional termasuk kepada destinasi pariwisata nasional (DPN) bersama Kota Bukittinggi. Selanjutnya dalam Rencana Induk Kepariwisataan provinsi Sumatera Barat, maka Kota Padang juga telah menjadi wilayah destinasi pariwisata provinsi (DPP) dengan destinasi kawasan strategisnya (KSPP) adalah Pesisir Selatan, Padang Pariaman, serta Kawasan Potensialnya adalah Kota Pariaman. Sehingga sebagai DPN, DPP Kota Padang memiliki potensi kepariwisataan yang besar; lebih kurang
169 destinasi wisata untuk dapat menarik kedatangan turis manca Negara maupun turis nusantara untuk datang dan berkunjung menggunakan waktu luangnya

2. Zona Kecamatan Kuranji memiliki total rata-rata biaya perjalanan yang paling tinggi di luar kecamatan Koto Tangah sebesar Rp 170.783,-- sedangkan zona kecamatan Bungus Teluk Kabung yang paling rendah yakni sebesar Rp 120.877,Tingginya rata-rata biaya perjalan ke kawasan BBI Lubuk Minturun ini ditentukan oleh rata-rata kunjungan perorang pertahun. Jika rata-rata kunjungan tinggi, maka biaya perjalalan akan rendah, tetapi sebaliknya apabila rata-rata kunjungan rendah, maka biaya rata-rata perjalanan akan lebih kecil. Nilai Surplus konsumen yang paling tinggi terdapat pada zona kecamatan Koto Tangah sendiri yang mencapai $\mathrm{Rp}$ 
99.875,23,- dan yang paling rendah adalah zona kecamatan bungus Teluk Kabung. Zona asal kunjungan yang memiliki rata-rata biaya yang paling kecil adalah pada zona destinasi utama pariwisata provinsi yakni Kota Padang, Kabupaten Pesisir Selatan, Kabupaten Padang Pariaman. Sedangkan zona asal kunjungan yang lebih rendah biaya ratarata keduanya adalah wilayah destinasi Kabupaten Agam, Lima Puluh Kota, Pasaman Barat. Di susul oleh zona destinasi pariwisata kabupaten Solok, Tanah Datar, Sijunjung dan Dharmasraya.

3. Peningkatan keikutsertaan aktifitas ekonomi masyarakat secara terintegrasi di sekitar kawasan agrowisata BBI Lubuk Minturun terlihat dari biaya ratarata perjalanan menuju lokasi agrowisata Lubuk Minturun berbanding lurus dengan nilai surplus konsumen dari lokasi wisata BBI Lubuk Minturun. Artinya, semakin rendah biaya rata-rata semakin besar jumlah kunjungan yang datang ke lokasi. Biaya-rata-rata yang paling rendah adalah berada pada zona kota Padang yang hanya mencapai Rp 196.800,- sedangkan biaya totalnya mencapai Rp 1.184.060,- per orang pertahun. Sedangkan surplus konsumen yang diperoleh oleh zona Kota Padang ini adalah sebesar $\mathrm{Rp}$ 2.267.236 pertahun. Disusul oleh kabupaten Agam total biaya perjalanan kunjungan adalah sebesar $\mathrm{Rp} 1.402 .200$ atau $\mathrm{Rp} 116.850$ perorang/bulan sedangkan surplus konsumennya mencapai Rp 2.265.863 per individu/tahun, atau hanya sekitar Rp 188.821 perorang/bulan dan nilai consumer surplus untuk wilayah kabupaten Agam adalah sebesar Rp 1.050 milyar pertahun. Dengan demikian pengunjung wisata yang berasal dari kabupaten Agam merupakan pengunjung yang potensial bagi destinasi agrowisata BBI Lubuk Minturun, disamping Kota Padang itu sendiri

\section{DAFTAR PUSTAKA}

10.22202/economica.2013.v1.i2.115
AIEST (1995). Real estate business and tourism development, ST-Gall: Edition AIEST.

Candela, G dan Cellini, R ( 2006). Investment in tourism market: A dynamic model of differential Oligopoly, Journal of environmental \& resource economies 35: 41-58, Springer.

Fauzi, A (2014). Valuasi Ekonomi dan Penilaian Kerusakan Sumberdaya Alam dan Lingkungan, IPB Press, Bogor.

Gawande, Kishore. at.al.(2009). Foreign informational lobbying can enhance tourism: evidence from the Caribbean, Policy research working paper 4834 . World Bank.

McElroy, J.L and Parry, C.E.(2010). The Characteristic of small Island tourist economies, journal of tourism and hospitality research 10:315, DOI.10.1057/thr.2010.11. Sage Published.

Pemprov Sumbar (2014) Peraturan Daerah No: 3 Tahun 2014 Tentang RIPKP Sumatera Barat Tahun 2014-2025

Shakya, Mallika (2009). Competitiveness Assessment of tourism in Sierra Leon: A Cluster- Based Approach, Journal fo Policy Research working paper Number WPS 5083, the World Bank, Poverty reduction and economic management network, International trade department October, 2009.

Vanhove, Norbert (2005). The economics of tourism destinations, Elseveir Limited Butterworth-Heinemann, UK 